\title{
Aspects of the population biology, life history and threats to Aloe ortholopha Christian and Milne-Redh.: A serpentine endemic from the northern Great Dyke of Zimbabwe
}

\begin{tabular}{|c|c|}
\hline \multicolumn{2}{|c|}{ 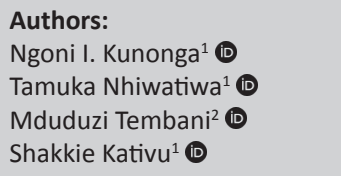 } \\
\hline \multicolumn{2}{|c|}{$\begin{array}{l}{ }^{1} \text { Department of Biological } \\
\text { Sciences, University of } \\
\text { Zimbabwe, Zimbabwe }\end{array}$} \\
\hline \multicolumn{2}{|c|}{$\begin{array}{l}{ }^{2} \text { Forest Research Centre, } \\
\text { Harare, Zimbabwe }\end{array}$} \\
\hline \multicolumn{2}{|c|}{$\begin{array}{l}\text { Corresponding author: } \\
\text { Ngoni Kunonga, } \\
\text { nkunonga@gmail.com }\end{array}$} \\
\hline \multicolumn{2}{|c|}{$\begin{array}{l}\text { Dates: } \\
\text { Received: } 17 \text { July } 2018 \\
\text { Accepted: } 11 \text { Dec. } 2018 \\
\text { Published: } 26 \text { Feb. } 2019\end{array}$} \\
\hline \multicolumn{2}{|c|}{$\begin{array}{l}\text { How to cite this article: } \\
\text { Kunonga, N.I., Nhiwatiwa, T., } \\
\text { Tembani, M. \& Kativu, S., } \\
\text { 2019, 'Aspects of the } \\
\text { population biology, life } \\
\text { history and threats to Aloe } \\
\text { ortholopha Christian and } \\
\text { Milne-Redh.: A serpentine } \\
\text { endemic from the northern } \\
\text { Great Dyke of Zimbabwe', } \\
\text { Bothalia } 49(1), \text { a2396. } \\
\text { https://doi.org/10.4102/abc. } \\
\text { v49i1.2396 }\end{array}$} \\
\hline \multicolumn{2}{|c|}{$\begin{array}{l}\text { Copyright: } \\
\text { (c) 2019. The Authors. } \\
\text { Licensee: AOSIS. This work } \\
\text { is licensed under the } \\
\text { Creative Commons } \\
\text { Attribution License. }\end{array}$} \\
\hline \multicolumn{2}{|l|}{ Read online: } \\
\hline 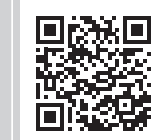 & $\begin{array}{l}\text { Scan this QR } \\
\text { code with your } \\
\text { smart phone or } \\
\text { mobile device } \\
\text { to read online. }\end{array}$ \\
\hline
\end{tabular}

Background: Aloe ortholopha is a rare endemic confined to serpentine soils of the Great Dyke of Zimbabwe. Its International Union for Conservation of Nature (IUCN) status is listed as Vulnerable; however, its population biology and life history are poorly documented.

Objectives: The aim of this article is to provide information on the population biology and life history of $A$. ortholopha through assessment of its size-class distribution, population size and density, reproductive output and fitness, and threats related to fire and mining.

Method: Circumference of $A$. ortholopha leaf rosette was used to ascertain size-class distribution. Population size and density were determined by enumerating flowering individuals. Percapita reproductive output was determined as mean number of flowers per plant, fruit set and mean number of seeds per fruit. Fitness was determined from seed germination capacity. Impact of fire and mining were recorded photographically.

Results: Determination of size-class distribution of $A$. ortholopha from three study sites (southern region [SR], central region [CR] and northern region [NR]) revealed a bell-shaped curve dominated by intermediate size classes. Population size (number of flowering individuals) ranged from 36 to 66 per site. This translated to a density of 4.0-7.3 flowering plants per hectare. Per-capita reproductive output, measured as mean number of flowers per plant, was significantly different in SR and CR compared to that in the NR region. Mean number of fruits per plant did not significantly differ across the three regions. Mean seed set per plant in CR and NR was significantly different to that in the SR region. Species fitness, as determined from in vitro germination assays, showed that seeds harvested from fire-damaged capsules have the lowest cumulative germination percentage. It was also observed that leaf rosettes curled up to form a ball that protects the apical centre of plants from fire damage.

Conclusion: A. ortholopha occurs in small population clusters of low density. The species has a low per-capita reproductive output characterised by production of many flowers, but with very low percentage fruit and seed set. The species has low fitness as evidenced by nominal recruitment of saplings and juveniles. Conspecific mates are frequently lost owing to fire and mining activities.

\section{Introduction and site description}

The Great Dyke of Zimbabwe spans some 530 kilometres $(\mathrm{km})$ in length, with a width ranging between $2 \mathrm{~km}$ and $12 \mathrm{~km}$. It runs in a linear south-southwest (SSW) to north-northwest (NNW) direction (Figure 1). The flora of the Dyke includes 30 serpentine endemics, 16 of which are restricted to serpentine-bearing soils of the northern Dyke, while eight occur in both the northern and southern Dyke (Mapaura 2002). According to Lande (1998) and Siebert, Van Wyk and Bredenkamp (2001), sites of high endemism and rare species need special protection in view of threats from anthropogenic activities. To date, habitats of the Dyke endemics have not received any protected status. Studies on the Dyke flora have largely been limited to checklists. BarclaySmith (1963) provided the first comprehensive checklist for a small section of the northern Dyke known as the Horseshoe Intensive Conservation Area. A follow-up study by Wild (1965) provided the first comprehensive compilation of a flora checklist covering the entire Dyke. That study identified 322 species, of which 20 were endemic to serpentine soils. Kunonga, Nhiwatiwa and Kativu (2017) provided the first report on population size structure of a serpentine endemic (Ozoroa longipetiolata) from the Great Dyke of Zimbabwe. 


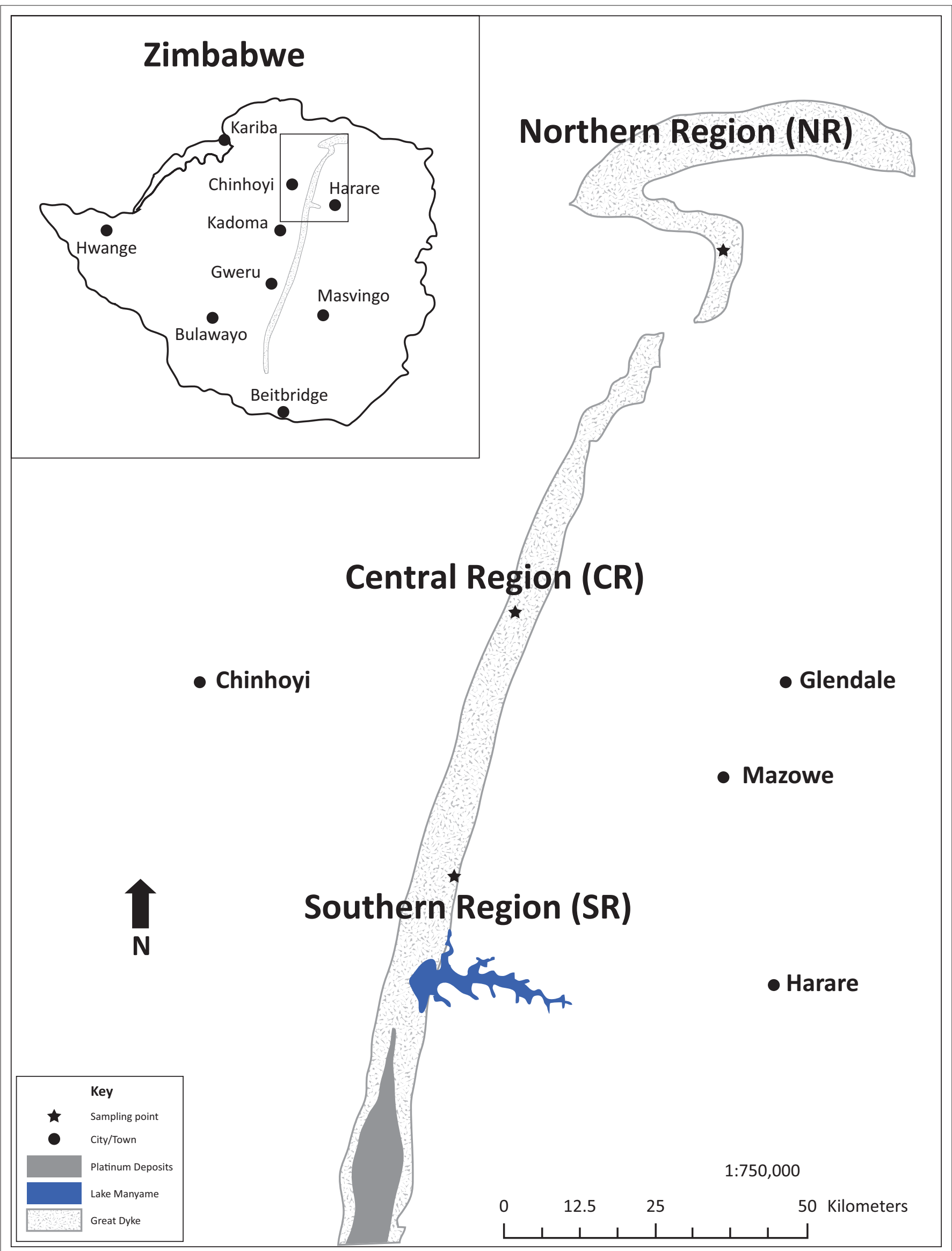

FIGURE 1: Map showing the Great Dyke of Zimbabwe. The northern portion of the Dyke is where the southern region (SR), central region (CR) and northern regions (NR) are situated. 
Studies by Werger, Wild and Drummond (1978) noted lower floristic diversity on the Dyke serpentine soils compared to adjacent non-serpentine soils. Proctor and Craig (1978) observed that non-serpentine Brachystegia spiciformis thrived on serpentine soils near riverine areas. According to Robertson and Meakin (1980), the high nickel (Ni) levels in Dyke serpentine soils prevent establishment of B. spiciformis by arresting mitosis and disrupting the cell membrane. Other studies by Wild (1974) and Brooks and Yang (1984) on mineral levels of Pearsonia metallifera, Blepharis acuminata, Merremia xanthophylla and Searsia wildii (=Rhus wildii) concluded that these Dyke endemics were hyperaccumulators of Ni. These findings were supported by studies of Hunter (1954) and Robertson (1985) that demonstrated how high Ni levels, associated with the Dyke serpentine soils, had deleterious effects on tobacco and Zea mays plants. Furthermore, transplant experiments revealed that non-serpentine species failed to establish or had retarded growth on serpentine soils of the Dyke (Wiltshire 1974).

Aloe ortholopha is an endemic succulent of the northern Great Dyke that is listed on the Southern African Plant Red Data List as Vulnerable (VU A1d A2b). The species is threatened by farming and mining activities (Mapaura \& Timberlake 2002). According to Barclay-Smith (1963), miningand farming-related disturbances along the Dyke date back to 1918. Maponga and Ruzive (2002) provided evidence for impact of tribute mining on the northern Dyke landscape.

The primary objective of the present study was to report on aspects of the population biology of A. ortholopha, which includes its population size structure, reproductive output and fitness, and fire and mining disturbance factors.

\section{Materials and methods \\ Study area and sampling sites}

Observations were made on the biogeographical range of A. ortholopha, a species restricted to serpentine soils of the northern Great Dyke of Zimbabwe that spans some $130 \mathrm{~km}$ from Lake Manyame (formerly Darwendale Dam, at $\left.17^{\circ} 43^{\prime} 10^{\prime \prime} \mathrm{S}, 30^{\circ} 32^{\prime} 14^{\prime \prime} \mathrm{E}\right)$ to Mavuradonha $\left(16^{\circ} 29^{\prime} 00^{\prime \prime} \mathrm{S}\right.$, $\left.30^{\circ} 55^{\prime} 11^{\prime \prime} \mathrm{E}\right)$. The width of the northern Dyke ranges from $2 \mathrm{~km}$ to $12 \mathrm{~km}$. The entire Great Dyke land cover is estimated to be $3000 \mathrm{~km}^{2}$ (Brooks \& Yang 1984). The Dyke terrain consists of undulating mountain chains, with steep slopes whose facades are littered with loose rocks, which greatly limit access to prospective sampling sites. Access to sampling sites is also restricted by mining companies that have exclusive mining rights to large swaths of the Dyke. In addition, sites within the northern (NR) region are near the Mavuradonha wilderness where wild animals roam. As such, accurate determination of area of occupancy and population size of A. ortholopha was unattainable.

In light of these challenges, we identified over 42 subpopulations across the species distribution range. Most of these subpopulations were observed with the aid of binoculars as they were not easily accessible. These subpopulations tend to colonise steep slopes and form clusters that aggregate on serpentine soils with varying magnitudes of current and historical mining-related disturbances.

Sampling focused on selected accessible subpopulations that constituted the southern (SR), central (CR) and NR regions of the northern Great Dyke (Figure 1). Within each region, three subpopulations at least $1 \mathrm{~km}$ apart were randomly selected. A line transect spanning the length of each subpopulation was established. Three 1 ha plots were laid along each transect. Thus, for each region, nine plots were established, totalling 9 hectare (ha) of sampling area per region. The established plots accounted for at least $90 \%$ of all aloe plants that constituted the subpopulation. Each study site was visited several times from June through to November 2016, as part of an assessment of population sizeclass distribution, reproductive output and disturbance factors (fire and mining activities).

\section{Size-class distribution}

Size-class distribution was estimated by measuring the circumference of the leaf rosette of both reproductive and sterile individuals, including saplings and juveniles.

\section{Population size and density}

Population size was determined by enumerating all flowering individuals across the sampled subpopulations in each of the three regions of the northern Great Dyke. Density of flowering individuals per region was calculated by dividing the number of reproductive individuals by nine (number of hectares).

\section{Per-capita reproductive output}

In October 2016, there was a brief phenophase captured prior to floral abscission where the inflorescence of a reproductive individual displayed both fruits and wilting flowers. An enumeration of both developing fruits and wilting flowers per plant was made over several days at each site, to estimate the number of flowers and proportion of flowers that developed into fruit (Wilson et al. 2009). Number of flowers per plant and number of fruits per plant were determined from all individuals in a sampling site (Cousins 2013). Thirty fruits were harvested from five randomly selected individuals per sampled subpopulation and seed set was determined by dissecting the fruit and counting the number of seeds. This measure gave an estimate of the mean number of seeds per fruit (Wilson et al. 2009).

\section{Reproductive fitness}

Preliminary germination assays performed at room temperature (25 degrees Celsius $\left[{ }^{\circ} \mathrm{C}\right]$ ) revealed a percentage cumulative germination of less than 5\% (Figure 3). To improve on percentage cumulative germination, assays were performed using seeds placed under varying chemical and temperature treatments. Assays were performed using 
incubators and protocols set to the International Seed Testing Association standards (ISTA 2010). Seeds were treated with different concentrations $\left(10^{-3}, 10^{-4}\right.$ and $\left.10^{-5} \mathrm{M}\right)$ of gibberellic acid (GA) or potassium nitrate $\left(\mathrm{KNO}_{3}\right)$, and were prepared with sterile distilled water, incubated at $20^{\circ} \mathrm{C}, 25^{\circ} \mathrm{C}, 30^{\circ} \mathrm{C}$ and $20 / 30^{\circ} \mathrm{C}$, respectively. The control was seed treated with sterile, distilled water. Seed germination was defined as the appearance of a radicle $\geq 2$ millimetres $(\mathrm{mm})$. Germinated seeds were scored daily for 21 days, and periodically moistened under the respective treatments. For each treatment, four replicates containing 25 seeds were used, and randomly placed in the respective incubators.

\section{Fire and mining disturbances}

Photo documentation of the species was conducted in situ during the rainy season, dry season and then prior and post-veld fire (VF). Individuals of different size classes growing under shade and in open areas were documented. Seeds of fruits damaged by VF were harvested for viability tests by germination assays. Evidence of habitat destruction and fragmentation because of mining and mining-related activities was documented photographically.

\section{Statistical analysis}

A one-way analysis of variance (ANOVA) was performed to compare the per-capita reproductive output of the three regions with regard to the mean number of flowers per plant, mean number of fruits per plant and mean number of seeds per plant. Tukey's pairwise multiple comparison test of means was performed $(p<0.05)$.

A two-way ANOVA was performed to assess the effects of chemical treatments (seven levels) and temperature (four levels) and their interaction on germination percentage of A. ortholopha seeds. To determine the differences among the treatment means, Tukey's pairwise multiple comparison test was performed $(p<0.05)$.

\section{Results}

\section{Size-class distribution}

A. ortholopha, a stemless succulent, has a leaf rosette that exhibits seasonal plasticity. During the wet season or when the plant grows under shade of a nurse plant or rock, the leaf rosette displays a horizontal shape that increases its
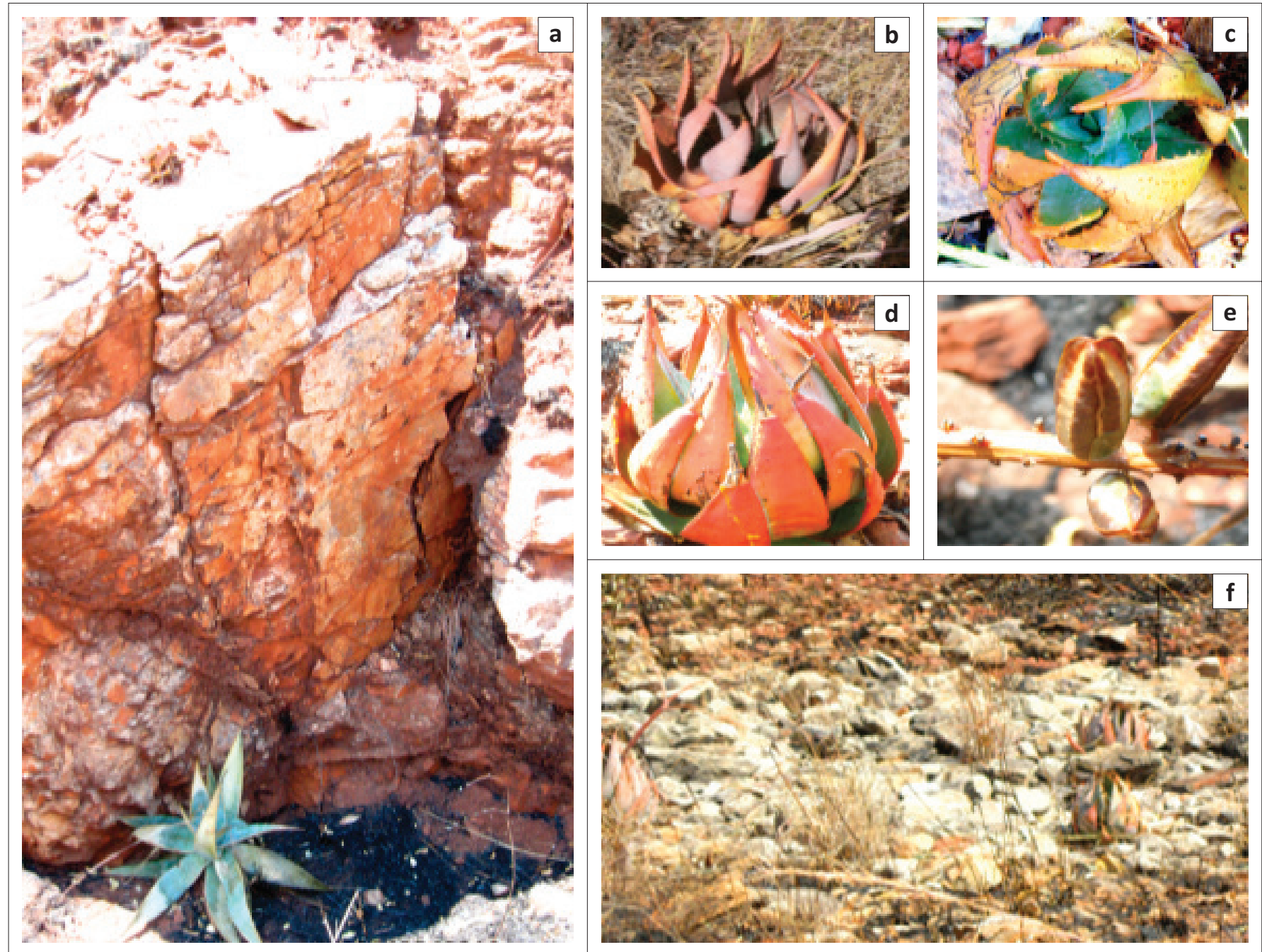

Source: Photos taken by Ngoni Ishe Kunonga

FIGURE 2: (a) Nurse rock providing shade and possibly minimising fire damage to the plant. (b)-(d) Leaf rosette forming a ball protecting the core from direct sunlight and veld fire damage. (e) Fruits exposed to veld fire in situ. (f) Rocky site occupation with little herbage. 
circumference, exposing the rosette core (Figure 2a). During the dry, hot season, the leaf rosette curls up towards the centre, forming a ball that covers the apical centre (Figure 2b-d). Population size-class distributions were determined in the three regions to assess the recruitment capacity of the species. A. ortholopha exhibited a bell-shaped frequency distribution in all three Dyke regions (Figure 3).
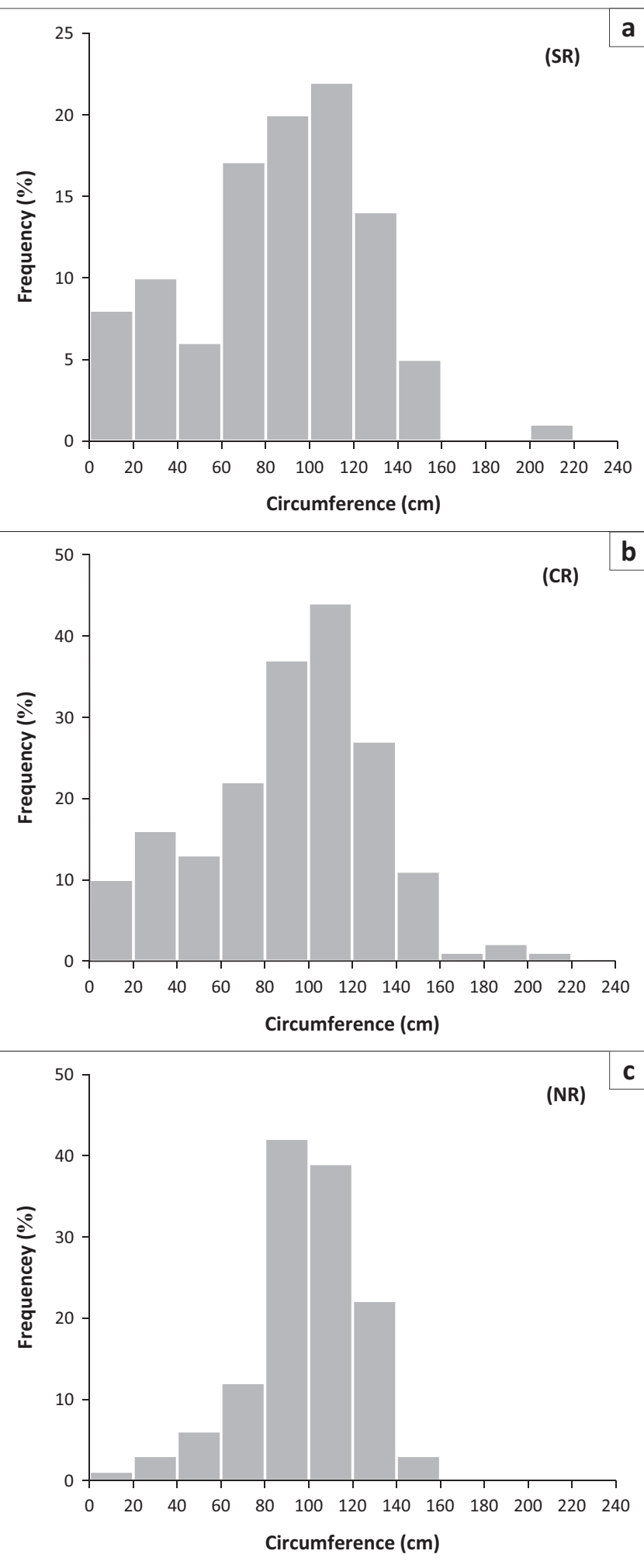

FIGURE 3: Frequency of size-class distribution of $A$. ortholopha in the three regions: northern region (NR), central region (CR) and southern region (SR).
The least number of sapling and/or juvenile size classes were recorded in the NR region. The largest size classes were observed in the SR and CR region (Figure 3).

\section{Population size, density and per-capita reproductive output}

Population size, as a count of number of flowering individuals, revealed that the $\mathrm{CR}$ region had the highest number of flowering individuals, 66 on 9 ha plots with a corresponding density of 7.3 flowering individuals per ha (Table 1). The CR region also exhibited the largest number of non-flowering individuals, 118 per 9 ha plot, with a corresponding density of 13.2 non-flowering individuals per ha. Assessment of the per-capita reproductive output showed that the CR regions had the highest total number of flowers produced at 6692. A one-way ANOVA revealed no significant $(p<0.05)$ differences with respect to the mean number of flowers per plant between SR and CR regions; however, both regions were significantly different to the NR region. There was no significant difference across the three regions with respect to mean fruit set per plant. However, the mean number of seed set per fruit was statistically similar between the CR and NR regions, while both regions were significantly different from the SR region.

\section{Reproductive fitness}

A two-way ANOVA showed significant $(p<0.05)$ interaction between temperature and treatment that affected the cumulative percentage of germination of $A$. ortholopha seeds (Table 2). Germination was poor in almost all the treatments at a temperature of $30^{\circ} \mathrm{C}$ (Figure 3). When treatments were assessed separately, potassium nitrate treatments (KNO3, KNO4 and KNO5) set at concentrations $10^{-3}, 10^{-4}$ and $10^{-5} \mathrm{M}$, respectively, recorded higher germination percentage at $25^{\circ} \mathrm{C}$. Seed exposed to VF exhibited low germination

TABLE 1: Summary statistics of $A$. ortholopha surveyed on 9 ha plots.

\begin{tabular}{lccc}
\hline Variables & SR & CR & NR \\
\hline Number of non-flowering plants & 66 & 118 & 83 \\
$\begin{array}{l}\text { Population size (flowering plants) } \\
\begin{array}{l}\text { Population density (number of } \\
\text { flowering plants/ha) }\end{array}\end{array}$ & 36 & 66 & 45 \\
Fruit set percent per plant (\%) & 33.5 & 42.7 & 5 \\
Mean number of flowers per plant & $122.4 \pm 71.9^{\mathrm{a}}$ & $101.4 \pm 72.7^{\mathrm{a}}$ & $71.7 \pm 41.6^{\mathrm{b}}$ \\
Mean number of fruits per plant & $40.9 \pm 38.3 .9^{\mathrm{a}}$ & $42.5 \pm 39.4^{\mathrm{a}}$ & $46.7 \pm 39.5^{\mathrm{a}}$ \\
Mean number of seed per fruit & $72.8 \pm 13.4^{\mathrm{a}}$ & $91.2 \pm 14.7^{\mathrm{b}}$ & $86 \pm 13.2^{\mathrm{b}}$ \\
\hline
\end{tabular}

Note: The acronyms SR, CR and NR represent the southern, central, northern regions of the Great Dyke of Zimbabwe respectively (Figure 1). Means with different superscript letters denote groups that are statistically different $(p=0.05)$. For example, the mean number of flowers per plant of SR and CR regions shares a same superscript ( $\left.{ }^{(}\right)$denoting that they are statistically similar to each other while both are statistically different to NR region with the superscript (b).

TABLE 2: A two-way analysis of variance showing the effects of chemical and temperature treatments and their interaction on the germination of A. ortholopha seeds.

\begin{tabular}{lcccc}
\hline Source of variation & SS & Mean square & $\boldsymbol{F}$ & $\operatorname{Pr}>\boldsymbol{F}$ \\
\hline Treatment & 91.0937500 & 13.0133929 & 3.51 & 0.0021 \\
Temperature & 122.5937500 & 40.8645833 & 11.02 & $<0.0001$ \\
Treatment $\times$ temperature & 190.5312500 & 9.0729167 & 2.45 & 0.0017 \\
\hline
\end{tabular}

Note: SS is the sum of squares; $F$-value represents the difference in variation among sample means to variation among groups, while $\operatorname{Pr}>F$ provides the probability for the $F$-value. 
percentage regardless of temperature. Seeds treated with $10^{-5}$ M GA exhibited the highest cumulative germination rate at $25^{\circ} \mathrm{C}$. A . ortholopha recorded low seed cumulative germination rates under different temperature and chemical treatment, suggestive of low overall fitness (Figure 4).

\section{Fire and mining disturbances}

Outer leaves of the rosette formed a parasol protecting the core of both juvenile and adult plants from direct sunlight by providing shade to the delicate core while also protecting the core from annual VF (Figure $2 \mathrm{c}-\mathrm{d}$ ). The fruit formation phenophase of $A$. ortholopha coincided with annual VFs, with fruits displaying fire damage (Figure 2e). Figure $2 f$ shows that individuals growing on rocky soils were less

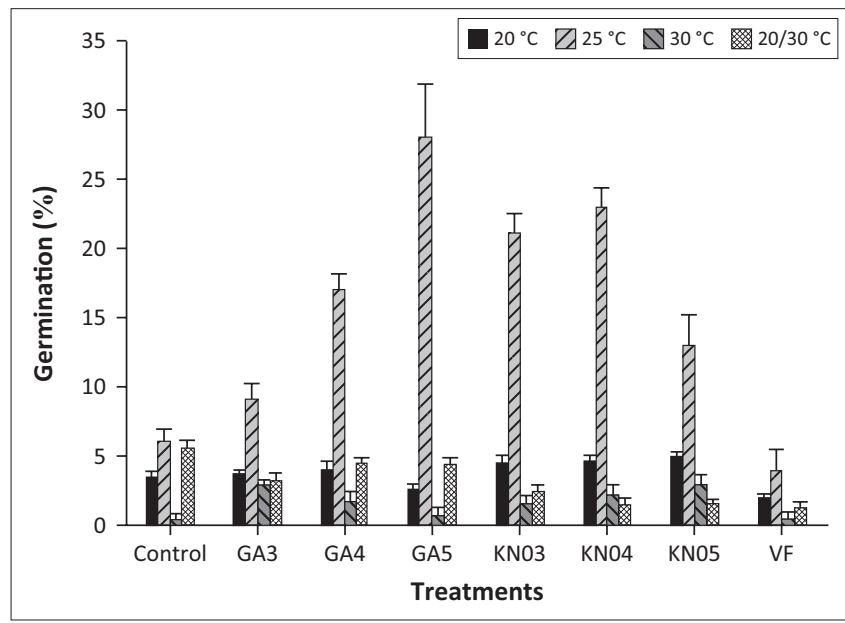

FIGURE 4: Germination assay results performed for 21 days using seeds pooled from three regions (southern, central and northern regions). Under the respective temperature, the control was seed treated with sterile distilled water. The remaining seed were treated with gerberellic acid (GA3, GA4 and GA5) or potassium nitrate (KNO3, KNO4 and KNO5) set at concentrations $10^{-3}, 10^{-4}$ and $10^{-5} \mathrm{M}$, respectively. Seeds harvested from fruits exposed to veld fire (VF) were incubated at the respective temperatures. prone to fire damage. Saplings establishing on rock crevasses were also less prone to fire damage.

Figure $5 a-c$ illustrates the anthropogenic-driven habitat destruction and fragmentation because of open cast mining. Open cast mining formed large mining dumps on selected, disused dumps. There was evidence of re-establishment of the species on these disused dumps (Figure 5d).

\section{Discussion}

A. ortholopha exhibited a bell-shaped size-class distribution dominated by middle size-class individuals, with fewer small and large class sizes. The bell-shaped distribution pattern is generally indicative of an unstable population with low recruitment and loss of adult reproductive class sizes. For threatened rare endemics, recurring fire disturbance is an important factor in their recruitment effort. To this end, postVF visits showed loss of $A$. ortholopha saplings because of incineration of individuals on sites with herbage. A. ortholopha saplings that established on rock crevices appeared to be protected from fire. Kumara plicatilis (=Aloe plicatilis), from the Western Cape province of South Africa, exhibits a similar fire avoidance strategy. Cousins (2013) reported that for K. plicatilis, there appeared to be a trade-off between growing on unfavourable rocky sites and protection from VFs, which resulted in stunted growth. With no historical records, it is not clear whether A. ortholopha on rocky microsites exhibits size plasticity similar to that recorded for K. plicatilis.

Several studies have attributed the bell-shaped population size distribution to anthropogenic disturbances, episodic recruitment and rainfall pattern. Anthropogenic disturbance was a key factor in determining a bell-shaped population size distribution pattern of Sclerocarya birrea (Helm \& Witkowski 2012). In the present study, episodic recruitment
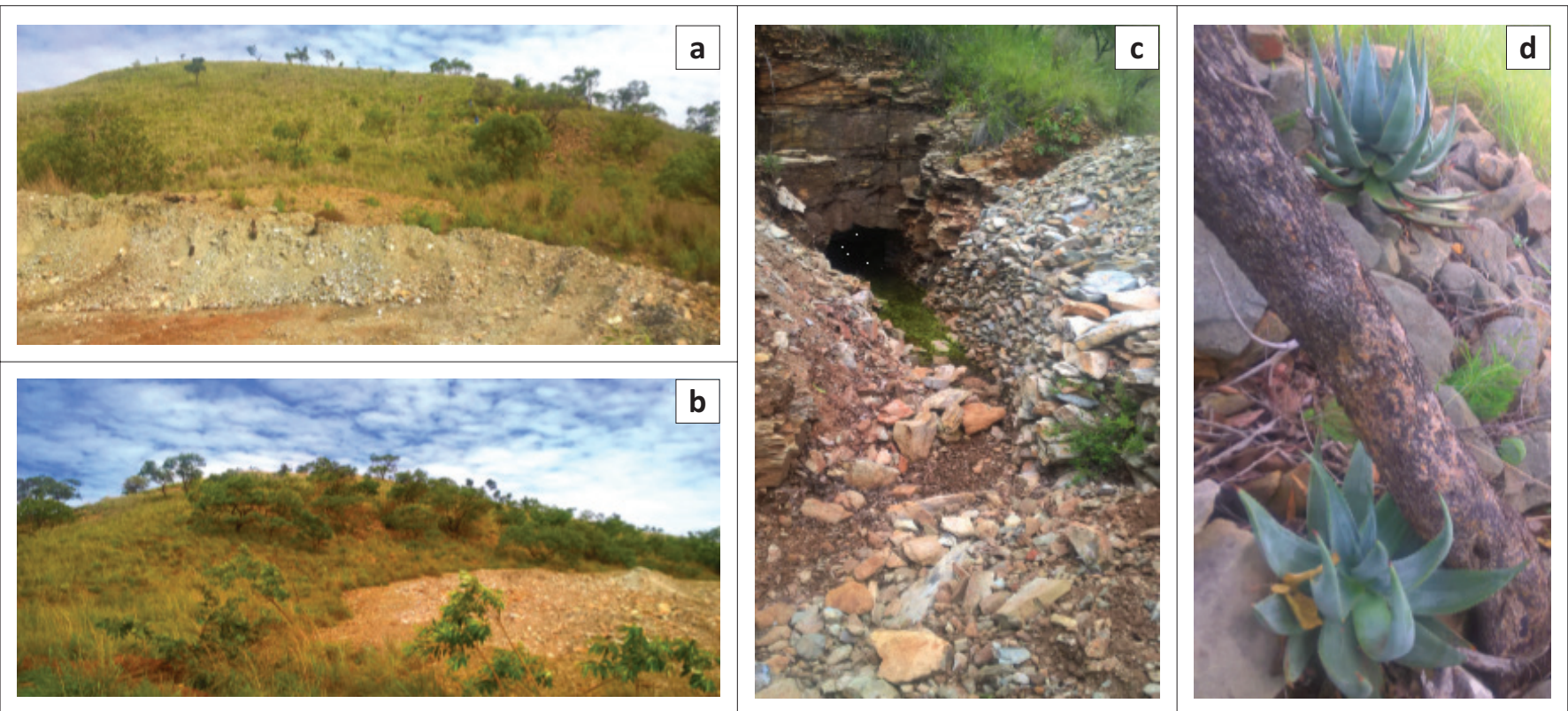

Source: Photos taken by Ngoni Ishe Kunonga

FIGURE 5: (a)-(c) Sites showing habitat loss and destruction by open cast mining and shallow shaft mines that litter the Dyke. (d) Reclamation of an abandoned mining site by $A$. ortholopha. 
of $A$. ortholopha at the subpopulation level was observed at Mapinge Pass and Vanad Mine, as no flowering individuals were observed during the 2012 and 2014 flowering seasons, yet in all other years, the subpopulations flowered. Studies by Brum (1973), Van Blerk (2013), and Cousins, Witkowski and Pfab (2014) indicated correlation between total precipitation and episodic recruitment resulting in a bell-shaped curve of in Aloidendron dichotomum (=Aloe dichotoma), Carnegiea gigantean (a desert succulent) and K. plicatilis (=A. plicatilis), respectively.

Fire appeared to retard or lower the germination capacity of seeds harvested from capsules exposed to VF in situ. Seeds exposed to fire generally recorded the lowest germination rates, which partly explains the low recruitment levels represented by the bell-shaped distribution pattern.

A. ortholopha subpopulations tend to be small, isolated, with sparsely distributed individuals. Populations with similar structure were shown to be susceptible to stochastic disturbance factors that could lead to local extirpation (Munzbergova 2006). Small populations tend to have low fruit set, seed set and seed germination capacity. A. ortholopha had low numbers of reproductive individuals. Such populations were reported to suffer from increased inbreeding (Morgan 1999; Reed 2005). They also tend to face increased mate finding challenges when conspecific mates are lost because of habitat destruction. This subsequently results in reduced population size and density (Steven \& Waller 2007). Continued loss of conspecific mates, coupled with small population size and low density, may lead to genetic bottlenecks (Gascoigne et al. 2009). Courchamp, Berec and Gascoigne (2008), on the other hand, pointed out that threatened conspecific subpopulations could be rescued by meta-populations (also referred to as 'rescue effect'). In addition, small fragmented populations were shown to be less attractive to pollinators (Agren 1996; Dauber et al. 2010). With each subpopulation being sparsely populated, this presents another reproductive hurdle as pollinators are not attracted to sparsely populated areas, which require higher energy expenditure for nectar foraging (Mustajarvi et al. 2001). The adaptive mechanism of A. ortholopha in attracting pollinators could include displaying large numbers of flowers per plant, making each pollination visit profitable for nectar seekers during periods when competing plants are not in flower.

The use of leaves as insulators against fire damage is a recurring phenomenon among aloes. Tall, single stemmed aloes, such as Aloe ferox, have their stem protected from fire damage and browsers by the remains of dead leaves (Bond 1983). High mortality rates recorded for A. ferox because of fire damage were primarily in size classes of less than 2.0 metres $(\mathrm{m})$, as they have a thinner insulator layer of dead leaves. Fires of a height range of $0.2 \mathrm{~m}-1.0 \mathrm{~m}$ produce the hottest flames, and may prove detrimental to aloes (Bond 1983). A. ortholopha is a stemless aloe whose height is less than $1.0 \mathrm{~m}$ (Kimberley 1974). The adaptation strategy of A. ortholopha against fire damage appears to be similar to that of Aloe peglerae (a stemless aloe) where the leaf rosette forms a protective ball that shields the delicate apical centre (Arena, Witkowski \& Symes 2015). The protective ball forms during the late dry season prior to the onset of rains. Results from the present study showed that individuals growing under shade or nurse rock do not form a protective ball. In addition, A. ortholopha appears to avoid fire damage by growing on shallow, rocky soils and in rock crevasses. These microsites are not favourable for the growth of herbage forming species, thus minimising fuel load. Mwafongo (2000) observed a positive linear correlation in the number of fire undamaged K. plicatilis plants and rockiness of the microsite. This is an adaptive strategy observed in several plants, including the fan aloe (K. plicatilis) and A. peglerae (Arena et al. 2015; Cousins, Witkowski \& Pfab 2016). Leaves of A. ortholopha saplings are too small to cover and protect the rosette core from fire damage. It is, therefore, not clear to what extent fire affects recruitment in A. ortholopha. This is a subject for future studies.

\section{Conclusions and recommendations}

Survival of $A$. ortholopha on the northern Great Dyke of Zimbabwe appears to be threatened by habitat loss resulting from mining-related activities and fire-related disturbances. Lack of historical records on population biology of the species and its conservation status prior to the present-day anthropogenic activities present challenges to the understanding of recruitment pattern and long-term survival of the species.

\section{Acknowledgements}

The authors are grateful to the invaluable assistance provided by the technical team from the Department of Biological Sciences at the University of Zimbabwe and that from the Forest Research Centre, Harare. The teams assisted in field sampling and technical assistance on the use of laboratory equipment.

\section{Competing interests}

The authors declare that they have no financial or personal relationships that may have inappropriately influenced them in writing this article.

\section{Authors' contributions}

S.K. supervised the project and assisted in experimental design and drafting of the manuscript. T.N. assisted in data analysis and drafting of the manuscript. N.I.K. was responsible for the experimental design, fieldwork and drafting of the manuscript. M.T. assisted in designing and monitoring of seed germination assays.

\section{References}

Agren, J., 1996, 'Population size, pollinator limitation, and seed set in the selfincompatible herb Lythrum salicaria', Ecology 77(6), 1779-1790. https://doi.org/ $10.2307 / 2265783$

Arena, G., Witkowski, E.T.F. \& Symes, C.T., 2015, 'Growing on rocky ground: Microhabitat predictors for site-occupancy of Aloe peglerae, an Endangered endemic species with a restricted range', South African Journal of Botany 100, 174-182. https://doi.org/10.1016/j.sajb.2015.05.022 
Barclay-Smith, R.W., 1963, 'A report on the ecology and vegetation of the Great Dyke within the Horseshoe intensive conservation area', Kirkia 4, 25-34.

Bond, W., 1983, 'Dead leaves and fire survival in Southern African tree aloes', Oecologia 58, 110-114. https://doi.org/10.1007/BF00384549

Brooks, R.R. \& Yang, X., 1984, 'Elemental levels and relationships in the endemic serpentine flora of the Great Dyke, Zimbabwe and their significance as controlling factors for the flora', Taxon 33(3), 392-399. https://doi.org/10.2307/1220976

Brum, G.D., 1973, 'Ecology of the saguaro (Carnegiea gigantea): Phenology and establishment in marginal populations', Madroño; a West American Journal of Botany 22(1), 195-204.

Courchamp, F., Berec, L. \& Gascoigne, J., 2008, Allee effects in ecology and conservation, 1st edn., Oxford University Press, New York.

Cousins, S.R., 2013, 'The ecology of Aloe plicatilis, a tree aloe endemic to the Cape fynbos, South Africa', MSc thesis, University of the Witwatersrand, Johannesburg, viewed 15 February 2016, from http://wiredspace.wits.ac.za/jspui/handle/10539/ 13695 ? mode $=$ full

Cousins, S.R., Witkowski, E.T.F. \& Pfab, M.F., 2014, 'Elucidating patterns in the population size structure and density of Aloe plicatilis, a tree aloe endemic to the Cape fynbos, South Africa', South African Journal of Botany 90, 20-36. https://doi. org/10.1016/j.sajb.2013.09.012

Cousins, S.R., Witkowski, E.T.F. \& Pfab, M.F., 2016, 'Beating the blaze: Fire survival in the fan aloe (Kumara plicatilis), a succulent monocotyledonous tree endemic to the Cape fynbos, South Africa', Austral Ecology 41(5), 466-479. https://doi. org/10.1111/aec.12318

Dauber, J., Biesmeijer, J.C., Gabriel, D., Kunin, W.E., Lamborn, E., Meyer, B. et al., 2010, 'Effects of patch size and density on flower visitation and seed set of wild plants: A pan-European approach', Journal of Ecology 98, 188-196. https://doi.org/ 10.1111/j.1365-2745.2009.01590.x

Gascoigne, J., Berec, L., Gregory, S. \& Courchamp, F., 2009, 'Dangerously few liaisons: A review of mate-finding Allee effects', Population Ecology 51, 355-372. https:// doi.org/10.1007/s10144-009-0146-4

Helm, C.V. \& Witkowski, E.T.F., 2012, 'Characterising wide spatial variation in population size structure of a keystone African savanna tree', Forest Ecology and Management 263, 175-188. https://doi.org/10.1016/j.foreco.2011.09.024

Hunter, J., 1954, 'Nickel toxicity in a Southern Rhodesian soil', South African Journal of Science 51, 133-135.

ISTA, 2010, International rules for seed testing, International Seed Testing Association Bassersdorf, Switzerland.

Kimberley, M., 1974, 'Aloe ortholopha', Excelsa 1, 45-46.

Kunonga, N.I., Nhiwatiwa, T. \& Kativu, S., 2017, 'Size structure of Ozoroa longipetiolate (Anacardiaceae): A serpentine endemic on the northern Great Dyke of Zimbabwe', Kirkia 19(1), 138-140.

Lande, R., 1998, 'Anthropogenic, ecological and genetic factors in extinction and conservation', Research in Population Ecology 40(3), 259-269. https://doi.org/ 10.1007/BF02763457

Mapaura, A., 2002, 'Endemic plant species of Zimbabwe', Kirkia 18(1), 117-149.

Mapaura, A. \& Timberlake, J.R., 2002, 'Zimbabwe', in J. Golding (ed.), Southern African red data list: Southern African Botanical Diversity Network Report No 14, p. 161 SABONET, Pretoria.
Maponga, O. \& Ruzive, B., 2002, 'Tribute chromite mining and environmental management on the northern Great Dyke of Zimbabwe', Natural Resources Forum 26, 113-126. https://doi.org/10.1111/1477-8947.00012

Morgan, J.W., 1999, 'Effects of population an size on seed production fragmented and germinability in grassland plant', Conservation Biology 13(2), 266-273. https:// doi.org/10.1046/j.1523-1739.1999.013002266.x

Munzbergova, Z., 2006, 'Effects of population size on the prospect of species survival', Folia Geobotanica 41, 137-150. https://doi.org/10.1007/BF02806475

Mustajarvi, K., Shkamaki, P., Rytkonen, S. \& Lammi, A., 2001, 'Consequences of plant population size and density for plant-pollinator interactions and plant performance', Journal of Ecology 89, 80-87. https://doi.org/10.1046/j.1365-2745. 2001.00521.x

Mwafongo, E., 2000, 'Population ecology of Aloe plicatilis (Liliaceae) in relation to disturbance', BSc thesis, University of Cape Town, Cap Town, viewed 21 March 2018, from https://open.uct.ac.za/handle/11427/26703

Proctor, J. \& Craig, G.C., 1978, 'The occurrence of woodland and riverine forest on the serpentine of the Great Dyke', Kirkia 11(1), 129-132.

Reed, D.H., 2005, 'Relationship between population size and fitness', Conservation Biology 19(2), 563-568. https://doi.org/10.1111/j.1523-1739.2005.00444.x

Robertson, A.A.I. \& Meakin, M.E.R., 1980, 'The effect of nickel on cell division and growth of Brachystegia spiciformis seedlings', Kirkia 12(1), 115-125.

Robertson, A.I., 1985, 'The poisoning of roots of Zea mays by nickel ions, and the protection afforded by magnesium and calcium', New Phytologist 100(2) 173-189. https://doi.org/10.1111/j.1469-8137.1985.tb02769.x

Siebert, S.J., Van Wyk, A.E. \& Bredenkamp, G.J., 2001, 'Endemism in the flora of ultramafic areas of Sekhukhuneland, South Africa', South African Journal of Science 97, 529-532.

Steven, J.C. \& Waller, D.M., 2007, 'Isolation affects reproductive success in lowdensity but not high-density populations of two wind-pollinated Thalictrum species', Plant Ecology 190(1), 131-141. https://doi.org/10.1007/s11258-0069196-2

Van Blerk, J., 2013, 'A simulated history of Aloe dichotoma recruitment and its link to rainfall: Insights from an isolated population near Kenhardt', BSc thesis, University of Cape Town, Cap Town, viewed 30 March 2018, from https://open.uct.ac.za/ handle/11427/14021.

Werger, M.J.A., Wild, H. \& Drummond, B.R., 1978, 'Vegetation structure and substrate of the Northern part of the Great Dyke, Rhodesia environment and plant communities', Vegetatio 37(2), 79-89. https://doi.org/10.1007/BF 00126831

Wild, H., 1965, 'The flora of the Great Dyke of Southern Rhodesia with special reference to the serpentine soils', Kirkia 5(1), 49-86.

Wild, H., 1974, 'Indigenous plants and chromium in Rhodesia', Kirkia 9(2), 233-241.

Wilson, A.-L., Ward, D., Brown, M. \& Johnson, S.D., 2009, 'Seed production in a threatened Aloe is not affected by bird exclusion or population size', Plant Ecology 203, 173-182. https://doi.org/10.1007/s11258-008-9524-9

Wiltshire, G., 1974, 'Growth of plants on soils from two metalliferous sites in Rhodesia', Journal of Ecology 62(2), 501-525. https://doi.org/10.2307/2258996 